\title{
Effect of Biologic Nurturing Baby Led Feeding on Post Sectio Caesarea Pain Scale In Majenang Hospital 2018
}

\author{
$\underline{\text { Reni Cahyanti1); Sinar Pertiwi2); Etin Rohmatin3) }}$ \\ teh.cahyanti@gmail.com
}

\begin{abstract}
Background: Post SC pain are the caused by the uterus contracts roomates state continuously in the uterine involution and pain from surgical incision. Pain management can be done by non-pharmacologically and pharmacologically to reduce pain symptoms that Appear. One of the non-pharmacological methods to reduce pain in post SC is Biologic Nurturing Baby Led Feeding position. Biologic Nurturing Baby Led Feeding position is breastfeeding by lying position while leaning in $15^{\circ}-64^{\circ}$ angle with the baby placed on the chest naturally.

Methods: The research method used was a quasi-experimental design with one group pretest posttest. The population in this study was the maternal caesarean section in Majenang General Hospital, Cilacap Regency, with a sample that was purposive sampling technique, the number of samples was 40 respondents.

Result: The results of the study showed that most of the pain before the Biologic Nurturing Baby Led Feeding had moderate pain as many as 27 people (67.5\%) and after the biologic nurturing baby led feeding, most had mild pain as many as 27 people $(67.5 \%)$, influence on the pain of the sectio caesarea in the Majenang General Hospital with $\rho$ value(0.000).

Conclusion: It was suggested that Standard Operating Procedures (SOPs) regarding Biologic Nurturing Baby Led Feeding implementation in post partum ward was developed to help decreasing pain in postpartum client with SC.
\end{abstract}

Keyword : Pain; Sectio Caesarea: Biologic Nurturing Baby Led Feeding

1,2,3) Health Polytechnic of Tasikmalaya Midwifery Department

Background. Every woman wants her labor went smoothly and can give birth to babies with perfect (Prawirohardjo, 2013). There are various methods of delivery that can be selected that vaginal delivery, delivery using the tools and operative delivery is sectio caesarea (SC). These methods were carried out with particular indications in order to save both mother and baby (Prawirohardjo, 2013).

Sectio Caesarea is the birth of a baby through an incision in the abdominal wall and the uterine wall (Cunningham et al., 2013). Indications SC according to (Prawirohardjo, 2013), namely: placenta previa, a narrow pelvis, threatening uterine rupture, prolonged labor, aberration, big baby, infant death, Gemelli, pre eclampsia and hypertension, cephalo pelvic disproportion and uterine dysfunction.

According to the World Health Organization (WHO), the average standard operating figures SC in a country is $10-15 \%$ (Gibbons et al., 2010), while in 2015 an estimated $22.5 \%$ of births in the world was done with SC. But overall labor SC reported in $25-50 \%$ of the total number of births in the world (M and JM, 2013).

Based on data from (Badan Penelitian dan Pengembangan Kemenkes RI, 2013) showed the level of labor SC in Indonesia by $9.8 \%$ with the highest proportion in Jakarta (19.9\%) and the lowest in Southeast Sulawesi (3.3\%), while in Central Java SC labor by $10 \%$. Proportion of births in Majenang hospital SC in 2017 amounted to $20.74 \%$ of the total labor 1,432 cases, while in January-September 2018 the number of SC amounted to $19.41 \%$ of total deliveries in 1082 cases (RSUD Majenang, 2017) (RSUD Majenang, 2018).

Complications postpartum in women after Sectio Caesarea is pain in the incision area, the potential for thrombosis, the potential for functional ability, decreased elasticity of the abdominal muscles and pelvic floor muscles, bleeding, bladder injury, infection, swelling of the lower extremities and impaired lactation (Utami, 2012)

Generally, the pain is felt during the first few days post SC. According (Julianti, 2014) that $68 \%$ of the mother post sectio caesarea experiencing difficulties with infant care, 
moving up and down on the bed and set a comfortable position during breastfeeding due to pain. The pain will cause the patient to postpone breastfeeding since the beginning of the baby (Aminah, 2011). Thus, breast milk as the best food for babies who have many benefits for babies and mothers can not be administered optimally (Purwandari, 2009).

Post SC pain resulting from the uterus that often contracted because it is still in the process of returning to its original shape and also the pain arising from the surgical incision. Pain that can be tolerated by the patients is the range of 1-3 or mild pain. Mild pain can easily tolerated after being given painkillers. If the pain is felt is level 4 or more than 4 , patients still feel pain after being given an analgesic drug. Patients with pain scale of 4 or more than 4 will experience mood swings and impaired physical activity (Gerbershagen et al., 2011).

Pain management was done nonpharmacological and pharmacological with the aim to treat the pain by eliminating the symptoms appear. Patients still feel pain and unable to adapt to the pain that is felt when the effect of analgesics is lost so that it takes nonpharmacological therapy (Warsono, Fahmi and Iriantono, 2019).

The use of non-pharmacological therapy will help patients reduce pain. Research shows that the use of non-pharmacological therapies help patients adapt to the pain so as to improve the quality of life, reduced use of analgesics, patients can immediately return to work, and provide different views about pain and its impact in the lives of patients. Reduction in pain as well as the economic impact, the patient can save expenses for visits to medical personnel and the purchase of anti-pain medications ( $M$ and $N, 2008$ ). One use of non-pharmacological therapy to reduce pain post SC is nursing baby led feeding Biologic nurturing position.

According to (Dewi, 2016), biologic nurturing namely baby led feeding postpartum mothers breastfeed lying position, leaning back, at an angle between $15^{\circ}-64^{\circ}$ then the baby is placed on the chest, and left attached by itself. This position makes the mother more comfortable, quieter, and more relaxed, minimize tension in the head, neck, shoulders and back. The research result (SD, JH and JM, 2008) say that the position laid-back / semi-reclining or lying felt more comfortable by new mothers, pain in the stitches or surgical wound is felt more minimal than sitting upright, thus supporting the mother for longer in breastfeeding

Position biologic nurturing baby led feedingis one of the feeding posistion recommended for post partum mothers SC because it was more relaxed. During the handling of post partum mothers with their pain with oral analgesics administration. Giving pharmacology does not aim to improve the client's own ability to control the pain. So it takes a combination of pharmacology to nonpharmacological pain control in order to decrease pain's sensation and the recovery period is not elongated. Non-pharmacological methods are needed to shorten episodes of pain that lasts only a few seconds or minutes (Yuliatun, 2008).

Preliminary studies in Majenang hospital in June 2018, there were 24 patients with post SC in July 2018 there were 17 patients with post SC, while in August 2018 there were 23 patients post SC. When averaged, each month there were approximately 22 patients with various indications SC. The results of post SC pain's assessment in 5 patients showed as many as four people say the pain was on the first day with an average pain scale 5 to scale 7 , and then the pain slightly reduced the numbers on the second day with a range of pain scale 4 through scale 6 , and only one person who did not complain of pain since the first day post SC. Information from the doctors and nurses, the pain in postpartum women by SC, treated with analgesics. Positions biologic nurturing baby led feeding has not been applied

Methods. This type of research is quantitative research. The method used is quasi experiment with one group pretest posttest design to determine the effect of nurturing biologic baby feeding led on post sectio caesarea pain scale in Majenang hospital.

O1 $----\rightarrow(X) ~------\rightarrow 02$

Information:

O1 : Pre test (intervention group)

O2 : Post test (intervention group)

(X) : Biologic intervention led nurturing baby feeding

Result and Discussion. Before performing biologic nurturing baby led feeding, the scale of pain in postpartum women by caesarean section can be seen in the table below: 
Table 1 Distribution of pain scale before biologic nurturing baby led feeding in Majenang Hospital

\begin{tabular}{lcc}
\hline Pain scale & $\mathrm{F}$ & $\%$ \\
\hline not Pain & 0 & 0 \\
Mild pain & 0 & 0 \\
Moderate pain & 27 & 67.5 \\
pain weight & 13 & 32.5 \\
Pain Very Heavy & 0 & 0 \\
\hline Total & 40 & 100 \\
\hline
\end{tabular}

The table above shows that the scale of pain before the biologic nurturing baby led feeding in Majenang hospital mostly have moderate pain as many as 27 people $(67,5 \%)$.

The biologic nurturing baby led feeding provides a benefit for decreasing the pain scale in women after SC delivery. The result can be seen in the table below:

Table 2. Distribution of pain scale after biologic nurturing baby led feeding in Majenang Hospital

\begin{tabular}{lcc}
\hline Pain Before biologic & $\mathrm{F}$ & $\%$ \\
nurturing baby led feeding & 0 & 0 \\
\hline not Pain & 27 & 67.5 \\
Mild pain & 12 & 30 \\
Moderate pain & 1 & 2.5 \\
pain weight & 0 & 0 \\
Pain Very Heavy & 40 & 100 \\
Total & \\
\hline
\end{tabular}

From the table above, shows that the scale of pain after the biologic nurturing baby led feeding in Majenang hospital mostly mild pain have as many as 27 people $(67.5 \%)$.

Statistical analysis of the test results above, it is known Asymp.Sig. (2-tailed) or $\rho$ value worth 0,000 . Because the value of 0,000 is less than $<0.05$, it can be concluded that the $\mathrm{Ha}$ accepted". This means that there is a change of pain scale before and after performing biologic nurturing baby led feeding.

The results of the study have been described previously obtained that the scale of pain before the biologic nurturing baby led feeding in Majenang hospital the majority had moderate pain as many as 27 people $(67.5 \%)$.

This was because the incision made in the body tissue during delivery so as to feel pain after sectio caesarea, after sectio caesarea while the mother should take care of the baby as well as herself

According to (Aminah, 2011), there are $68 \%$ post sectio caesarea women had trouble with infant care, moving up and down on the bed and set a comfortable position during breastfeeding due to pain. The pain will lead to patients since the beginning of delay breastfeeding her baby.

This was consistent with the results (Astutik and Kurlinawati, 2017) with the title of the effect of relaxation handheld finger to pain reduction in patients post sectio cesarea in Delima room Kertosono Hospital the results showed that pain in patients post sectio caesarea in the pomegranate Kertosono hospital before relaxation handheld finger dated 12 January to 12 February 2017 the majority had moderate pain as many as 13 people (65\%)

Based on the description of the results of research and theory can be harmonized that post sectio caesarea pain prior to treatment is to moderate pain scale.

Results of this research shows that the scale of pain after the biologic nurturing baby led feeding in Majenang hospital were the majority had mild pain as many as 27 people $(67.5 \%)$.

It was because of interventions to reduce the pain, the mother feel comfort to perform this feeding techniques (biologic nurturing baby led feeding) in this position with the slope $15^{\circ}-64^{\circ}$ able to provide flexibility to the mother so that the mother feel comfortable and also reduce pain.

According to (SD, JH and JM, 2008) this position allows the attachment is perfect when nursing mothers, but it also encourages neonatal movement by releasing up to 20 reflex neonatal primitive act as a stimulant to breastfeed, such as "reflex pedaling" hand pushing, legs kicking , front and rear head movements like "pecking" will help the baby move reaches the areola. Moreover, because the force of gravity will help the baby to enter the areola far into his mouth.

The delivery process causes fatigue, even trauma to the mother, which have an impact on postpartum pain incidence, as stated (N, 2011) that a person will feel an increase in pain sensation when the body experiences fatigue. In the biologic nurturing position baby led feeding, postpartum mothers breastfeed lying position, leaning back, at an angle between $15^{\circ}-64^{\circ}$ and then the baby was placed on the chest, and left attached by itself. In this way, the mother intervenes baby's position, both hands-free mother, holding the baby just to keep it from being knocked over, so as to make the mother more 
comfortable, quieter, and more relaxing to minimize tension in the head, neck, shoulders and back.

It was consistent with the results of the study (Rini and Susanti, 2018) no change before and after the intervention of nursing positions given biologic nurturing baby led feeding. The difference in mean rank more than 10 then, both clinically and statistically there is a significant difference between the pain scale before and after the intervention nursing positions biologic nurturing baby led feeding.

Then it could be harmonized with the findings that the administration of this kind of intervention, in addition to the feeding position is also good for pain reduction post SC.

The results of this research shows that there was a change in frequency of pain is of moderate to light prior to biologic nurturing baby led feeding as many as 27 people $(67.5 \%)$ and after becoming mild pain as many as 27 people $(67.5 \%)$. Statistical analysis of the test results above, it is known Asymp.Sig. (2tailed) orr valueworth 0,000 . Because the value of 0,000 is less than $<0.05$, it could be concluded that the "Ha accepted". This means that there is a change of pain prior to biologic nurturing baby led feeding and after biologic nurturing baby led feeding, so it can be concluded also that "biologic effects of nurturing baby feeding led to pain post sectio caesarea in Majenang hospital".

Differences in perceived pain of respondents supported by Telfer in (Fraser and Cooper, 2009) which states that pain is a multifactorial phenomenon of subjective, personal and influenced by a complex 85factor ontro psychological, biologic, cultural and economic factors. This difference indicates that the intervention of biologic nurturing baby led feeding is able to divert the pain tolerance and threshold of pain during and after the mother underwent breastfeeding and direct contact with the baby, with lactating mothers willing to adapt and respond to pain better, so that mothers are more tolerant to taste pain she endured.

Significant pain reduction in maternal post SC before and after the intervention was influenced by many factors both pharmacological and non-pharmacological. Intervention nursing positions biologic nurturing baby led feeding entered in pain therapy non-pharmacological, ie without the use of drugs, but to provide a technique to reduce the pain of distraction treatment that focus the patient on something other than pain, such as breastfeeding (Watiyah, 2013), This refers to the gate control theory which states that the impulses of pain will pass through the gates (sensory nerve endings) might be regulated or inhibited by the defense mechanisms along the central nervous system. Pain impulses delivered when the gate is in the open position and would be stopped when the gate was closed (Potter P.A dan Perry G.A., 2006). Biologic feeding position nurturing baby led feeding could be used as inhibitors (closing) so that nerve impulses can not walk freely and therefore can not transmit impulses or sensory messages to the sensory cortex. Efforts to close the defense is the basic theory of pain relief (Sinatra et al., 2010).

The results are consistent with research (Rini and Susanti, 2018) that the results showed a significant decrease in pain in women post SC before and after biologic nurturing baby led feeding intervention ( $p$ $<0.01$ ).

So we can conclude that with the provision of non-pharmacological interventions both in order to always give comfort to the mother is also able to reduce the pain of sectio caesarea.

Conclusion and Suggestions. Based on the results of research and discussion, its prove that a biologic effect of nurturing baby feeding led can reduce pain in post sectio cae sarea in Majenang hospitals, which could be described as follows: Pain scale before biologic nurturing baby led feeding in Majenang hospital the majority had moderate pain as many as 27 people $(67.5 \%)$. Pain scale after the biologic nurturing baby led feeding in Majenang hospital the majority had mild pain as many as 27 people $(67.5 \%)$. There is a biologic effect of nurturing baby feeding led to pain post sectio caesarea in Majenang hospital. Based on these conclusions, it was recommended that postpartum women with SC who experience pain can perform the biologic nurturing baby led feeding to reduce their pain.

Acknowledgements. Thanks to the researchers say to all those who have helped in completing this research.

\section{References}

Aminah, M. S. (2011) 'Baby's Corner', in 
Kamus Bayi 0-12 Bulan. Jakarta: Luxima.

Astutik, P. and Kurlinawati, E. (2017) 'Pengaruh Relaksasi Genggam Jari terhadap Penurunan Nyeri pada Pasien Post Sectio Caesarea', Strada Jurnal Ilmiah Kesehatan, 6(2), pp. 30-37. doi: 10.30994/sjik.v6i2.6.

Badan Penelitian dan Pengembangan Kemenkes RI (2013) Laporan Riset Kesehatan Dasar Tahun 2013. Jakarta.

Cunningham et al. (2013) Obstetri Williams. Jakarta: EGC.

Dewi, T. E. R. (2016) Asuhan Kebidanan kehamilan. Jakarta: Salemba Medika.

Fraser, D. M. and Cooper, M. A. (2009) Myles; Buku Ajar Bidan. Jakarta: EGC.

Gerbershagen, H. J. et al. (2011) 'Determination of Moderate-to-Severe Postoperative Pain on The Numeric Rating Scale: A Cut-Off Point Analysis Applying Four Different Methods', British Journal of Anaesthesia, 107(4), pp. 619-626. doi: 10.1093/bja/aer195.

Gibbons, L. et al. (2010) The Global Numbers and Cost of Additional Needed and Unnecessary Caesarean Sections Performed Per Year, Overase As a Barter To Universal Coverage, World Health Organization. Geneva. Available at: https://www.who.int/healthsystems/topics/ financing/healthreport/30Csectioncosts.pdf.

Julianti (2014) Materi Pelatihan Postnatal Care. Jakarta: Universitas Indonesia.

M, C. and N, C. (2008) 'The Impact and Effectiveness of Nurse-Led Care in the Management of Acute and Chronic Pain: a Review of the Literature', J Clin Nurs, 17(15), pp. 2001-13. doi: 10.1017/СВO9781107415324.004.

M, J. and JM, D. (2013) 'Methods of Term Labour Induction for Women with a Previous Caesarean Section', PubMed, 28(3), p. 2013. Available at: https://www.ncbi.nlm.nih.gov/pubmed/235
43582.

N, D. K. (2011) Buku Ajar Dasar Dasar Keperawatan Gawat darurat. Jakarta: Salemba Medika.

Potter P.A dan Perry G.A. (2006) Buku Ajar Fundamental Keperawatan. 4th edn. Edited by Y. Asih. Jakarta: EGC.

Prawirohardjo, S. (2013) IImu Kebidanan. Jakarta: Yayasan Bina Pustaka Sarwono Prawirohardjo.

Purwandari (2009) Pengaruh Terapi Latihan terhadap Penurunan Nilai Nyeri pada Pasien Post Sectio Caesaria, Universitas Muhammadiyah Yogyakarta. Universitas Muhamadiyah Surakarta. Available at: http://eprints.ums.ac.id/5880/1/J11005002 6.PDF.

Rini, S. and Susanti, I. H. (2018) 'Penurunan Nyeri pada Ibu Post Sectio Cesaria Pasca Intervensi Biologic Nurturing Baby Led Feeding', MEDISAINS; Jurnal IImiah IImu IImu Kesehatan, 1(2), pp. 83-88. doi: 10.22069/jwfst.2018.15021.1747.

RSUD Majenang (2017) Rekam Medis RSUD Majenang.

RSUD Majenang (2018) Rekam Medis RSUD Majenang.

SD, C., JH, M. and JM, H. (2008) 'Optimal Positions for The Release of Primitive Neonatal Reflexes Stimulating Breastfeeding', Early Human Development, 84(7), pp. 441-9. Available at:

https://www.ncbi.nlm.nih.gov/pubmed/182 43594.

Sinatra, R. S. et al. (2010) Acute Pain Management, ASA Publications. Available at:

https://anesthesiology.pubs.asahq.org/arti cle. aspx? articleid $=1933391$.

Utami, E. R. (2012) 'Antibiotika, Resistensi, Dan Rasionalitas Terapi', Sainstis, 1(1), pp. 124-138. doi: 10.18860/sains.v0i0.1861.

Warsono, W., Fahmi, F. Y. and Iriantono, G. 
(2019) 'Pengaruh Pemberian Teknik Relaksasi Benson Terhadap Intensitas Nyeri Pasien Post Sectio Caesarea Di Rs Pku Muhammadiyah Cepu', Jurnal IImu Keperawatan Medikal Bedah, 2(1), p. 44. doi: 10.32584/jikmb.v2i1.244.

Watiyah (2013) Perbedaan Skala Nyeri Persalinan Kala I Sebelum Dan Sesudah Massage Counter Pressure Pada Ibu Bersalin Di Wilayah Kerja Puskesmas Pekuncen Kabupaten Banyumas, repository.shb.ac.id. Stikes Harapan Bangsa Purwokerto. doi: 10.1017/CBO9781107415324.004.
Yuliatun, L. (2008) Penanganan Nyeri Persalinan dengan Metode Nonfarmakologi. Malang: Banyumedia Publishing. doi: 